\title{
CURRENT PRACTICES OF EXPERIENTIAL LEARNING IN CONSTRUCTION AND TECHNOLOGY PROGRAMS
}

\author{
AHMED ABDELATY ${ }^{1}$ and K. JOSEPH SHRESTHA ${ }^{2}$ \\ ${ }^{1}$ Dept of Construction, Southern Illinois University Edwardsville, Edwardsville, USA \\ ${ }^{2}$ Dept of Engineering, Engineering Technology, and Surveying, East Tennessee State \\ University, Johnson City, USA
}

\begin{abstract}
Construction education is dynamic and practice oriented. As such, effective construction programs require significant collaboration with the construction industry. This collaboration, in the form of internship or cooperative programs, increase the student readiness for the job market by providing valuable field experience. Construction programs in the United States (US) established several internship requirements that range from being optional to multiple required internships. This study focuses on scanning the current internship requirements set by construction and engineering technology programs in the US by gathering information including; 1) Number and length of required internships, 2) Internship prerequisites, 3) Internship deliverables, 4) assessment method. The outcome of this study is expected to help construction programs improve their internship or cooperative requirements by considering the prevailing practices developed by other schools. Additionally, the study provides recommendations to enhance the effectiveness of internship for positive experiential learning.
\end{abstract}

Keywords: Internship, Field-experience, Cooperative education, Teaching methodology, United States.

\section{INTRODUCTION}

The construction industry is characterized by being a dynamic and transformative to new and effective practices. As such, preparing future construction professionals requires the inclusion of a dynamic and flexible curriculum. One of the best practices to create such a curriculum is to include experiential learning as one of the learning instruments. Experiential learning happens when the learner gains knowledge through the transformation of experience (Kolb 2014). In a construction management curriculum, this transformation can be effectively achieved through internships and cooperative education (co-ops) experiences. Many construction management programs require students to complete at least one internship or co-op before graduation. However, the requirement varies from one program to another.

Maintaining a continuous connection between construction management programs and the industry is vital to enhance the quality of future graduates. Some programs have realized the importance of this continuous connection and includes an extensive co-op or internship requirement in their curriculum while other programs are still lagging. One of the advantages of including a strict internship or co-op requirement is exposing students to actual construction 
experience outside the classroom. This allows students to apply knowledge gained in the classroom to real-life construction projects. It further enhances students' classroom learning experience as they will be better equipped at identifying and understanding the potential applications of classroom knowledge in their future work environment.

From the university's perspective, programs benefit from keeping an active link with the industry to validate and improve their curriculum. However, requiring several credit hours internship or co-op requirement may pose a challenges on some students to graduate on time especially since several programs require such internships or co-op to be completed one or two semester before graduation. Additionally, some programs may struggle with distributing their required credit hours for graduation between experiential learning-based courses and other required traditional courses.

The objective of this study is to survey the internship and co-op requirements of construction engineering, technology, and management programs from Southeast region and Great Lakes region of Associated Schools of Construction (ASC) which includes the state of Alabama, Florida, Georgia, Mississippi, North Carolina, South Carolina, Virginia, and Tennessee, Illinois, Ohio, Indiana, Michigan, Kentucky, and Wisconsin. Based on the data collected from public websites, the authors analyze the advantages and disadvantages for different internship requirements. The authors also compare the similarities and differences in the internship requirements between the programs in Southeast region and Great Lakes region. Additionally, recommendations for programs that plan to include an internship or co-op requirement are presented.

\section{LITERATURE REVIEW}

The experiential learning model is not something new. The theory has been proposed and implemented more than 40 years ago. Kolb (2014) reformulated the experiential learning theory. There are 4 structural dimensions underlying the process of experiential learning. Kolb's model involves four areas of experiential learning 1) reflective observation, 2) active experimentation, 3) abstract conceptualization and 4) concrete experience. These areas would be encountered through an experiential learning activity such as an internship or a co-op experience. An internship has innumerous definitions; however, it can be defined as a supervised work experience with an intention of encountering an experiential learning strategy (O'Neill 2010). According to O'Neill (2010), an internship should be a deliberative form of learning that has a cycle of feedback for improvement to support learning goals and objectives.

Tener et al. (2001) analyzed the effectiveness of experiential learning from internships in construction engineering and management. The study examined reports submitted by 170 construction engineering and management students after finishing their internships. The authors analyzed the language in the reports and match it to the four learning modes suggested by Kolb's experiential learning model. Active experimentation and reflective observation are the highest learning modes encountered during the internship. The study also reported a significant development in student's self-efficacy because of the internship experience.

In disciplines close to construction management, McCarthy and McCarthy (2006) integrated experiential learning into business curricula. Experiential learning as a learning pedagogy gives an opportunity to the students to learn from personal encounter and actual work experience. This learning process occurs through cooperative education placements, internships, job shadowing, and classroom-based hands-on activities. McCarthy and McCarthy (2006) investigated the effectiveness of incorporating job shadowing in a junior level business communication course. Sixty-eight students participated in an 8-hour job shadowing assignment. Students were asked to 
write a reflective paper on what they experienced. An exit survey indicated that $100 \%$ of the students found that job shadowing was helpful or very helpful activity (McCarthy and McCarthy 2006). Similarly, Gault et al. (2000) investigated the relationship between the student success and exposure to experiential learning in the form of internship. The study shows that experiential learning plays an important role in preparing students for entry job-level market. Through a survey, students who interned before were able to secure jobs faster than students who never interned. Students who previously had an internship reported securing higher monetary compensation from their first job compared to students with no internship experience.

Doel (2008) describes an approach that aims at maximizing the benefits gained through industry internships. The approach adopted the School of Engineering at the University of Queensland enhances the students' reflection on their internship experience. Students are required to report logs and critical learning activities. Afterwards, students are required to analyze their significant learning activities by analyzing the situation, self-impact, interpretation, and decision. Doel (2008) also notes an important observation related to experiential learning: students actually learn from reflecting on their experience and taking responsibility.

\section{OBJECTIVES AND METHODOLOGY}

The main objective of this study is to investigate the adoption and implementation of internship and co-op education in the US construction engineering, technology, and management programs. This objective is achieved by: 1) collecting data on the internships and co-op requirements of the construction programs in Southeast and Great Lakes regions, 2) analyzing the variation of such requirements using descriptive statistics, 3) compare the requirements among the programs from the two regions, 4) providing recommendations based on the prevailing internship or co-op requirements.

\section{DATA}

The authors used ASC's regional directory to identify the colleges and universities in Southeast and Great Lakes regions that offer associate or bachelor's degrees in construction engineering, technology, or management. The Southeast region consist of eight states (Figure 1): Alabama, Florida, Georgia, Mississippi, North Carolina, South Carolina, and Tennessee; the Great Lakes Region consists of six states: Illinois, Indiana, Kentucky, Michigan, Ohio, and Wisconsin. The authors studied programs from 15 colleges and universities from Southeast region and 23 from Great Lakes region.

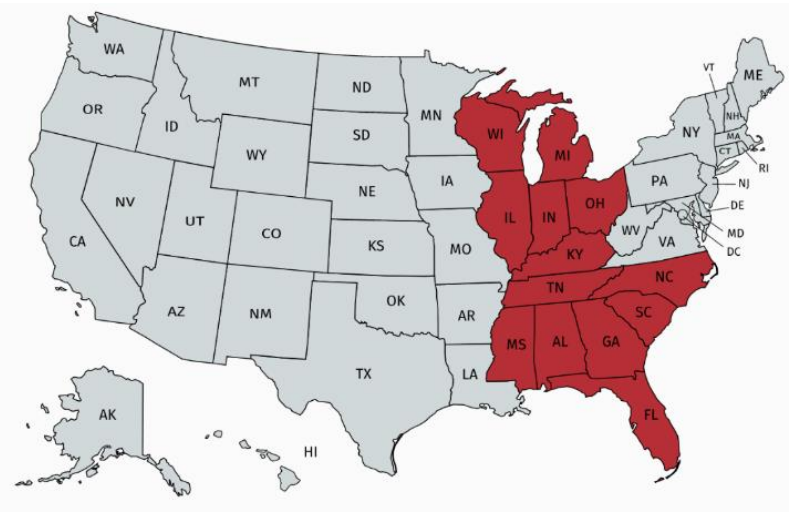

Figure 1. States covered in the survey. 
Most of the data were obtained from their course catalog and program overview pages from their websites. The data collected include a) number and length of required internships, b) internship prerequisites, c) internship deliverables, and d) assessment methods.

\section{INTERNSHIP REQUIREMENTS}

The results of the survey are summarized in Table 1. More than half the programs surveyed have internship and/or co-op requirements for graduation. More percentage of programs in Great Lakes region require internship and/or co-op. While median number of internship and/or co-op hour requirement in Great Lakes regions is higher, the average is higher in the Southeast region. Overall, the median number of hours required by the programs in both regions combined is 400 hours.

Table 1. Descriptive statistics of internship and co-op requirements.

\begin{tabular}{lrrr}
\hline \multicolumn{1}{c}{ Descriptions } & Southeast & Great Lakes & Combined \\
\hline Total Number of Programs Surveyed & 27 & 23 & 50 \\
Average Internship and/or Co-op Hours & 530 & 401 & 438 \\
Median Internship and/or Co-op Hours & 400 & 490 & 400 \\
Percentage of Programs Requiring Internships or Co-Op & $48 \%$ & $83 \%$ & $64 \%$ \\
\hline
\end{tabular}

Figure 2a shows that most of the programs do not require any internship and/or co-op while 16 programs surveyed requires at least one. Some programs required up to 5 internships. Figure 2.b shows that most of the programs prefer internships over co-op.

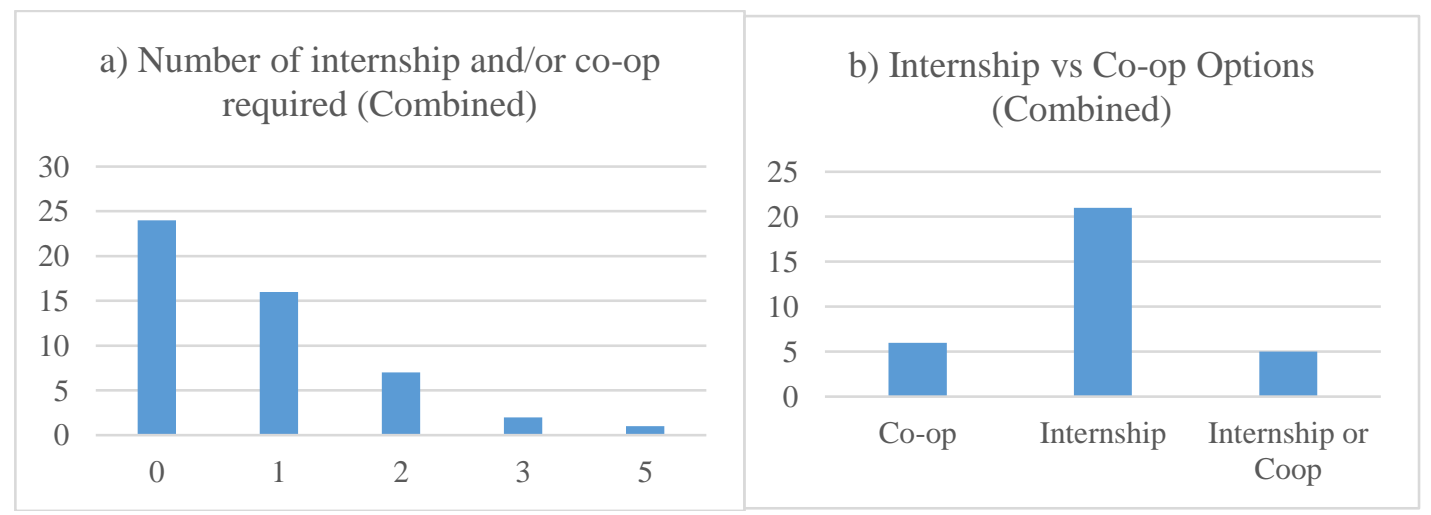

Figure 2. Number of internship and/or co-op requirements in the combined region.

Figure 3 shows the distribution of the number of hours required for graduation in the construction programs in Southeast and Great Lakes regions and their combination. The number of hours required varies widely in the programs surveyed. In all cases, 400 hours is the most common number of hours for internship and/or co-op. Those that require any such hours, the requirement is as low as 80 hours to as high as 800 hours. The second most common number of such hours is 300 .

The study further noticed variation in requirements to take the internship/co-op positions. Some programs required junior or senior standings, others have various other course as 
prerequisites before enrolling for the class, and others require departmental approval. Further the total number of credit hours for the internship also varied from 1 to 12 credits when it is required.

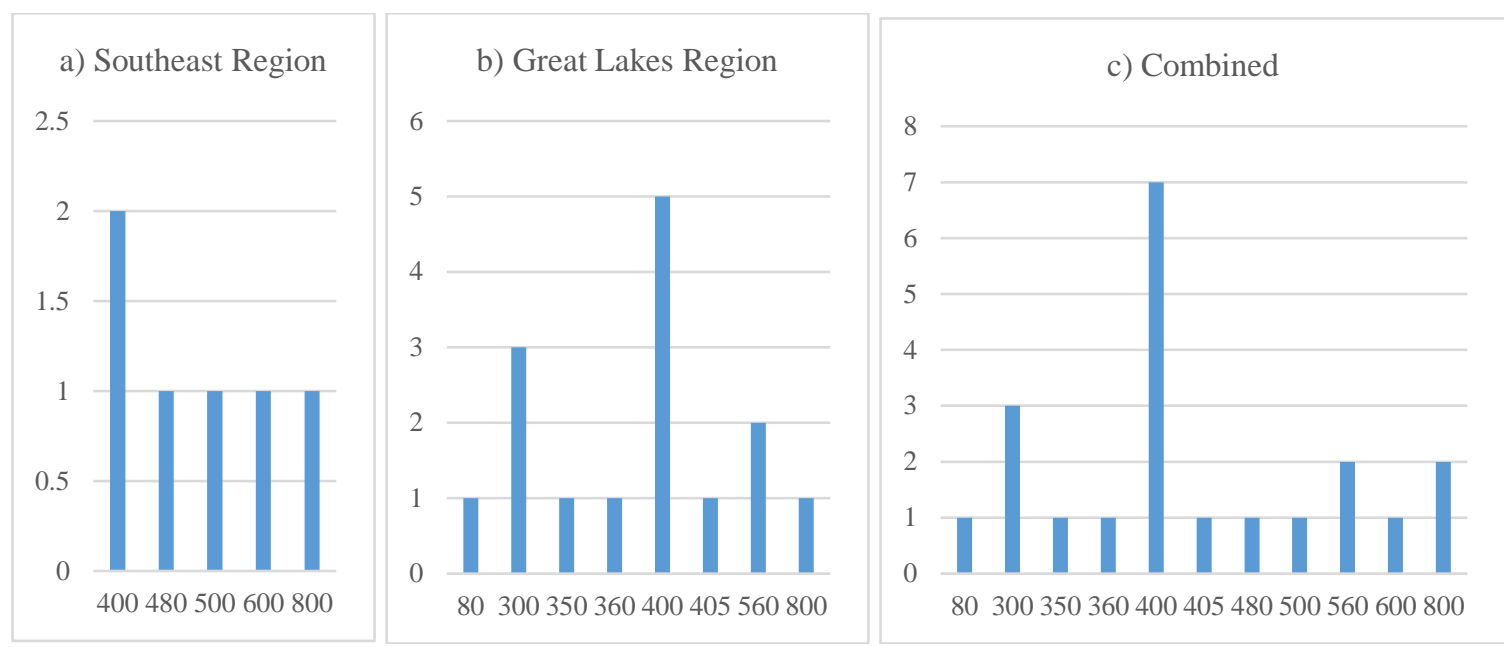

Figure 3. Distribution of number of internship and/or co-op required for graduation.

Many programs require a formal presentation and/or reports from the student and documentations from the company once internships and/or co-op are completed. This is a good practice to have.

\section{DISCUSSION AND CONCLUSION}

Based on the data collected, the authors believe that a 400 hours internship is a reasonable and important requirement for graduation. Requiring more than one internship or co-op can create graduation hurdles especially when the construction market is not growing. Students may face difficulties finding internship opportunities to graduate on time. In addition, academics have noted that many states in the United States are pushing universities to lower the number of credit hours required for finishing a degree. This means that some schools may face challenges to redesign their curriculum.

Few programs require finishing 12 credit hours of internship or co-op experience. This requirement is considered one of the toughest requirements observed among all programs surveyed. On the other hand, not requiring any internship to graduate can significantly lower the level of readiness of some students with no prior construction experience. Based on the data collected, the prevalent requirement is one internship for 400 hours.

Most of the programs require interns to be in a junior or senior standing. Few other programs require specific coursework on safety or specific certification such as OSHA 10. The authors believe that having a safety coursework or certification is a good practice to ensure the interns safety in construction jobsites. Some programs have a publicly available internship handbook which describes the intern, industry mentor, and academic supervisor responsibilities and roles. The authors believe that this a good practice to identify the responsibilities and expectations before the start of the internship.

One major concern observed in regards with the effectiveness of internships is how the number of hours are counted. There is no discussion in any of the internship handbooks on this topic. The number of hours required for the internship completion should be tied to the 
productivity and type of tasks assigned to the intern. Only one university have segregated the maximum number of hours for counted from various types of works such as management, trades, labor, and volunteering experience. As such, it's important to communicate the level of expectation with the interns and their industry mentors regarding the level of work and tasks assigned. It is also important to note that Hajshirmohammadi (2017) indicated that experiential learning activities should be assessed by the level of understanding compared to control group. While this may be challenging to incorporate in construction and technology internships, the idea of deeper level of internship assessment should be explored.

As for future research, it is recommended to conduct a nationwide survey of the internship requirement and practices. In addition, a questionnaire survey that would target academic supervisors, students, and industry mentors would greatly reveal important insights regarding the best practices of experiential learning.

\section{References}

Doel, S., Measuring Student Reflection During Engineering Internships, WACE Asia Pacific Conference, 2008.

Gault, J., Redington, J., and Schlager, T., Undergraduate Business Internships and Career Success: Are They Related?, Journal of Marketing Education, 22(1), 45-53, 2000.

Hajshirmohammadi, A., Incorporating Experiential Learning in Engineering Courses, IEEE Communications Magazine, 55(11), 166-169, 2017.

Kolb, D. A., Experiential Learning: Experience As The Source of Learning and Development, FT Press, 2014.

McCarthy, P. R., and McCarthy, H. M., When Case Studies Are Not Enough: Integrating Experiential Learning into Business Curricula, Journal of Education for Business, 81(4), 201-204, 2006.

O’Neill, N., Internships as a High-Impact Practice: Some Reflections on Quality, Peer Review, 12(4), 4-8, 2010.

Tener, R. K., Winstead, M. T., and Smaglik, E. J., Experiential Learning from Internships in Construction Engineering, Proceedings of the 2001 ASEE Annual Conference \& Exposition, Albuquerque, NM, June 24 - 27, 2001. 